\title{
DISSEMINATED INTRAVASCULAR COAGULATION IN OBSTETRICS: ETIOPATHOGENESIS AND UP TO DATE MANAGEMENT STRATEGIES
}

\author{
Sadik SAHIN ${ }^{1}$, Mustafa EROGLU ${ }^{1}$, Sermin TETIK ${ }^{2}$, Kadir GUZIN $^{3}$ \\ 1 Department of Obstetrics and Gynecology, Zeynep Kamil Gynecologic and Pediatric Training and Research Hospital, Istanbul \\ 2 Department of Biochemistry, Marmara University, Faculty of Phparmacy, Istanbul \\ 3 Department of Obstetrics and Gynecology, Medeniyet University, Göztepe Education and Research Hospital, Istanbul
}

\section{SUMMARY}

Disseminated intravascular coagulation related to obstetric conditions is rarely seen but is associated with high morbidity and mortality. Recently, pathophysiology of disseminated intravascular coagulation has not been understood well and, therefore, effective and permanent treatment strategies are missing. In this review, we try to discuss the etiology, current diagnostic approaches and management strategies of disseminated intravascular coagulation from the perspectives of clinicians.

Key words: disseminated intravascular coagulation, morbidity and mortality, pregnancy

Journal of Turkish Society of Obstetrics and Gynecology, (J Turk Soc Obstet Gynecol), 2014; Vol: 11, Issue: 1, Pages: 42-51

\section{OBSTETRIDE YAYGIN DAMAR İÇI KOAGÜLASYON: ETYOPATOGENEZ VE GÜNCEL TEDAVI STRATEJILERI}

\section{ÖZET}

Obstetrik nedenlere bağlı olarak gelişen yaygın damar içi koagülasyon, nadir görülmesine rağmen morbidite ve mortalitesi oldukça yüksek seyreden klinik bir durumdur. Günümüzde yaygın damar içi koagülasyonun patofizyolojisi tam olarak aydınlatılamamış olup, bu nedenle etkili ve kalıcı tedavi yöntemleri henüz geliştirilememiştir. Bu derlemede, klinisyenin bakış açısıyla obstetrik pratikte karşımıza çıkan yaygın damar içi koagülasyon değerlendirilmiş ve güncel literatür bilgisi ışığında yaygın damar içi koagülasyonun etyopatogenezi, tanısal yaklaşımları ve tedavi alternatifleri tartışılmıştır.

Anahtar kelimeler: gebelik, morbidite ve mortalite, yaygın damar içi koagülasyon

Türk Jinekoloji ve Obstetrik Derneği Dergisi, (J Turk Soc Obstet Gynecol), 2014; Cilt: 11, Sayl: 1, Sayfa: 42-51

\section{INTRODUCTION}

At present time, obstetrical bleedings remain to be the worldwide's main cause of maternal mortality and early identification of factors leading to hemorrhage and rapid management of the underlying pathological process is the key stone of the treatment ${ }^{(1)}$. The most important pregnancy related conditon leading to bleeding with high mortality and mobidity rates is dissemniated intravascular coagulation (DIC).

Dissemniated intravascular coagulation was first described by Joseph DeLee in 1901 as a fatal hemorrhagic diathesis following placental abruption(2). The underlying pathophysiology in DIC is systemic activation of the

Address for Correspondence: Dr. Sadık Şahin. Opr. Dr. Burhanettin Üstünel cad. no: 10, Üsküdar, İstanbul Phone: +90 (532) 5181595

e-mail: drsadiksahin@gmail.com

Received: 12 May 2013, revised: 27 July 2013, accepted: 28 July 2013, online publication: 31 July 2013 
coagulation cascade leading to extensive fibrin deposition and subsequent microvascular thrombosis. Furthermore, patients exhibit a tendency for severe bleeding associated with the consumption of platelets and coagulation factors $^{(3,4)}$. Clinically, DIC may lead to a wide range of pictures from unnoticed intravascular thrombosis and microvascular damage to uncontrollable bleeding. DIC always evolves secondary to predisposing clinical condition $^{(5)}$. The real incidence of obstetrical DIC is unknown since it represents a wide spectrum ranging from mild to severe. Various studies done showed that the incidence of DIC in all pregnancies was 0.02-0.07 $\%(6,7)$. Maternal mortality associated with DIC vary from 6 to $24 \%$ and postpartum hysterectomy, massive blood transfusions and acute tubular necrosis are listed as the main maternal morbidity indicators $(7,8)$. Therefore, early detection of these predictors of DIC and timely intervention of this life-threatening condition is very important.

\section{CONDITIONS LEADING TO DISSEMINATED INTRAVASCULAR COAGULATION}

Obstetrical and non-obstetrical etiologies leading to DIC are listed in Figure 1. In a study reported by Darrien et al, the identified causes of obstetrical DIC were listed as placental abruption (\%37), postpartum bleeding (\%29), severe pre-eclampsia/HELLP syndrome (Hemolysis, Elevated Liver Enzymes, Low Platelet Count) (\%14), acute fatty liver of pregnancy (\%8), sepsis $(\% 6)$ and amniotic fluid embolism $(\% 6)^{(8)}$. Intrauterine fetal loss is also reported as a cause of $\operatorname{DIC}{ }^{(9)}$.

Placental abruption, is a pathology charaterized by rupture of the maternal decidual artery resulting in hemorrhage into the deciudal-placental interface ${ }^{(10)}$. Although, the underlying pathophysiology is not fully understood, placental insufficiency and uteroplacental hypoperfusion are postulated to be the cause ${ }^{(11)}$. It has also been shown that pro-inflammatory cytokines cause premature seperation of of the placenta(12). Studies reported showed a positive relationship between the degree of placental seperation and fibrin deposition as well as thrombocytopenia suggesting that the coagulation process initially starts in the placental bed ${ }^{(13)}$. Similar to trauma patient, in postpartum bleeding, the severe amount of blood loss and subsequent consumption of coagulation factors is held responsible for the development of DIC(14).
Figure 1: The reasons of Disseminated Intravascular Coagulation (DIC).

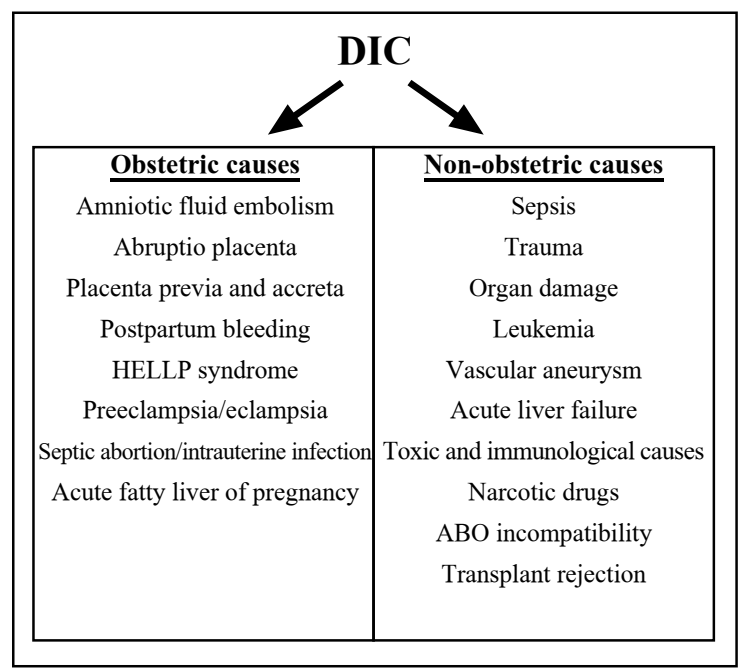

In pre-eclampsia, the maternal inflammatory response formed against trophoblasts results in a systemic endothelial dysfunction. Thus, vasodilator prostaglandins decrease and thrombocyte aggregation and uteroplacental ischemia increases $(15,16)$.

HELLP syndrome, is a syndrome characterized by endothelial cell damage in the liver(17). It is believed that substances originating in the placenta cause an acute inflammatory state in the hepatic endothelial cells ${ }^{(18)}$. This inflammatory cascade is reported to be different then the inflammatory mediators involved in the process leading to the DIC picture(19).

Septic abortion causes DIC by triggering the release of inflammatory substances which are eventually disrupting the coagulation mechanism. Studies done showed that endothelial dysfunction plays a key role in the pathophysiology of septic abortion ${ }^{(20)}$.

Amniotic fluid embolism, is a clinical condition that could be observed during the delivery and postpartum upto $48 \mathrm{hrs}$. It has been reported that $70 \%$ of the cases occurred pre-partum ${ }^{(21-24)}$. Clinically, it's characterized as hypotension, cardiac arrhythmia, cyanosis, dyspnea, altered mental status and bleeding. Clark et al estimated the maternal mortality rate attributed to amniotic fluid emboli as $61 \%{ }^{(22)}$. Recenly published studies, reported various rates ranging $6-44 \%(25,26)$.

Acute fatty liver is mostly reported in the third trimester and has a fulminant course. Studies done identified genetic deficiencies in the beta oxidation of fatty acids played a role in the pathogenesis of acute fatty liver(27). Severe hepatic dysfunction and Anti-Thrombin III deficiency are hypothesized to be involved in the course of DIC $(28,29)$. 


\section{PATHOPHYSIOLOGY}

Disseminated intravascular coagulation is a systemic thrombohemorrhagic disorder developing secondary to certain clinical conditions. In order to understand the changes it is essential to have a fund knowledge of the normal coagulation mechanisms. The coagulation cascade is demonstrated in Figure 2. The coagulant response is initiated with the formation of Tissue Factor (TF) and subsequent binding to Factor VIIa. As a result, Factor $\mathrm{X}$ is activated and thus prothrombin is converted to thrombin (Factor IIa) ${ }^{(30)}$. Thrombin, plays a central role in coagulant, anticoagulant fibrinolytic, antifibrinolytic and antifibrinolytic mechanisms ${ }^{(31)}$.

Figure 2: tPA: tissue plasminogen activator.

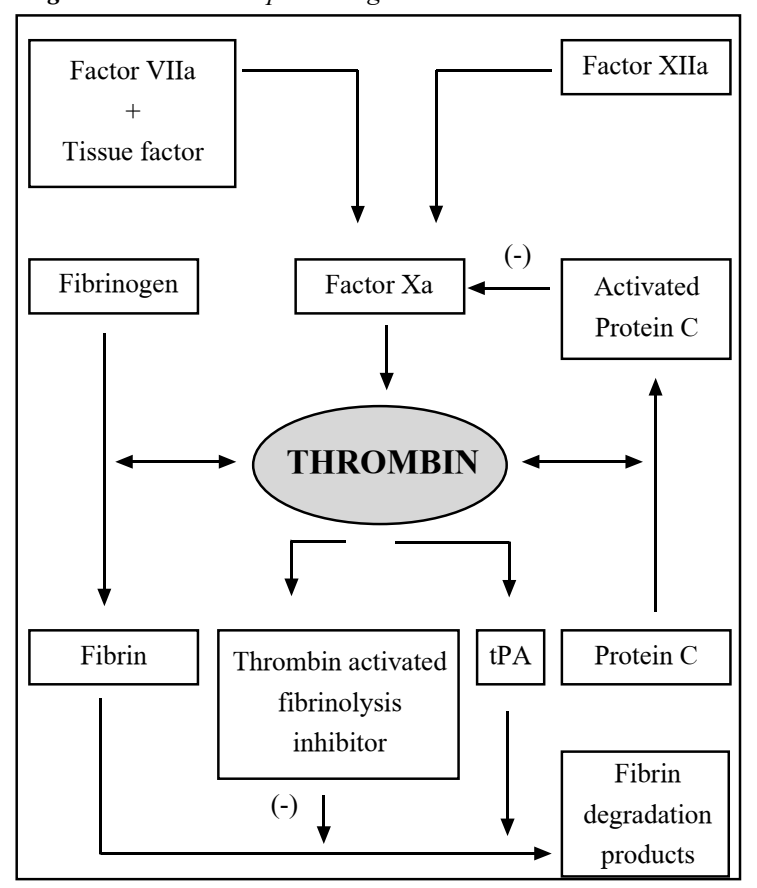

The coagulant response is initiated with the formation of Tissue Factor (TF) and subsequent binding to Factor VIIa. As a result, Factor X is activated and thus Prothrombin is converted to Thrombin (Factor IIa).

Besides being a a procoagulant converting fribrinogen to fibrin, thrombin also controls anticoagulation by activating protein C. Fibrinolysis, is degradation of fibrin to fibrin split products via tissue plasminogen acticator (tPA) activated by thrombin.

Thrombin also regulates fibronolysis by activating the active fibrinolysis inhibitor (TAFIa).

Therefore, thrombin plays a cental role in coagulant, anti-coagulant, fibrinolytic and anti-fibrinolytic mechanisms. Shows negative inhibition. bleeding (Reference \#65 is used in to build this figure).

\section{Physiological changes in the coagulation mechanisms}

\section{during pregnancy}

During the pregnancy substantial changes take place in the hemostasis mechanism. Significant rise in the majority of the coagulation factors, and decrease in the level of natural anticoagulants and fibrinolytic activity are the most important physiological changes notable through pregnancy. These alterations lead to a state of hypercoagulability and an increased risk of thrombembolism. Following the delivery, the period of time when the placenta is being retrieved has the highest level of thrombotic activity due to release of thromboplastic substances. Fibrinogen levels double during the pregnancy compared to prior to the pregnancy. Also, D-Dimer levels rise during the pregnancy (32-34).

In response to activation of cytokines, release of procoagulant factors or exposure to pro-coagulant factors, all predisposing factors leading to DIC initiate the activation of the coagulation cascade as part of the systemic inflammatory response(35). The DIC pathogenesis is a complex mechanism in which the invivo increased thrombin production plays a central role. Increased tissue factor production, anticoagulation system dysfunction, insufficient fibrinolysis and increased anionic phospholipid concentration leads to development of DIC ${ }^{(36)}$. The pathophysiology of DIC is demonstrated in Figure 3.

Figure 3: The Pathophysiology of Disseminated Intravascular Coagulation (DIC).

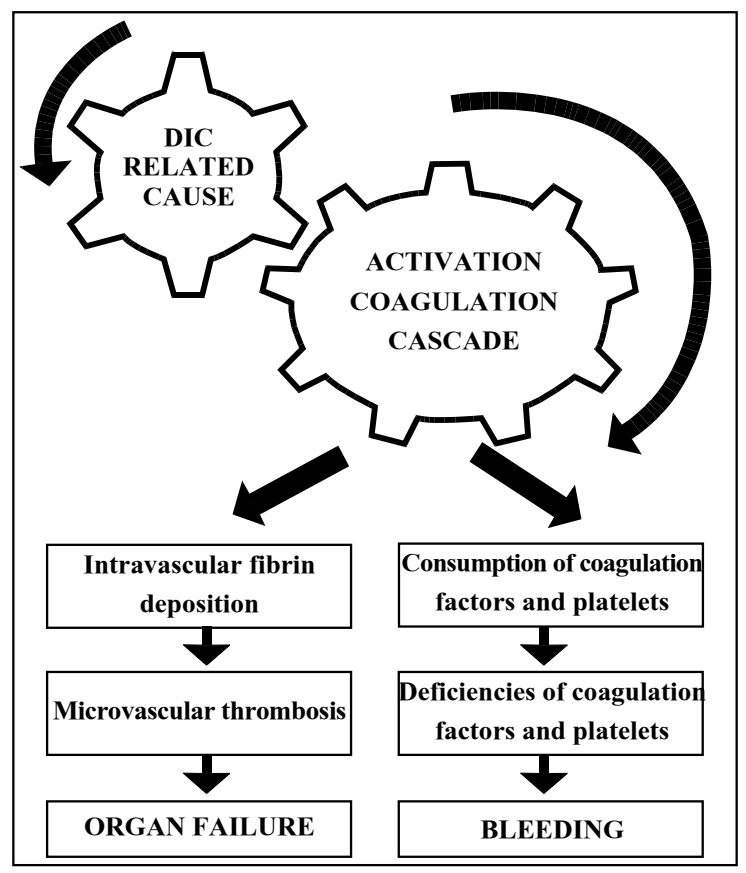




\section{CLINICAL FINDINGS}

Disseminated intravascular coagulation is an aquired thromboembolic disease where the clinical findings usually depend on the underlying pathology. In the early stage (acute period), a massive thrombin production takes place as a result of exposure of blood to excessive amount of tissue factor. Subsequently the coagulation cascade is triggered acutely(36). This condition can present itself with a clinical picture varying from bleeding to thrombosis. End organ damage at the microvascular level ensues as result of fibrin accumulation in the intravascular bed. The overall conditon of patients' are often critical in disseminated intrvascular coagulation along with parallellism between the findings and severity of illness. Bleeding is usually the most frequent clinical finding. It manifests itself usually as echymosis, petechia, mucosal oozing, prolonged bleeding at vein pucnture sites, surgical incision sites and from various systems, especially the gastrointestinal system. Altered mental status, acute renal failure, hypoxia and hypovolemic shock may occur as a result of blood loss ${ }^{(36,37)}$. Although, rarely seen, abdominal compartment syndrome may also be encountered in these patients. Abdominal compartment syndrome, is a condition in which tissue perfusion and organ functions are adversely affected due to increased pressures in an enclosed anatomical space leading to dysruption of the circulation. It is a clinical picture that presents itself as cardiovascular insufficiency, respiratory failure, renal dysfunction, increased intraabdominal pressure and abdominal distension and improves with prompt surgical decompression(38)

\section{DIAGNOSIS}

There is no single laboratory test to diagnose DIC. The diagnosis is established based on clinical suspicion and supportive laboratory tests. The tests used include laboratory parameters indicative of procoagulant and fibrinolytic substance activation, inhibitor consumption and organ damage or failure ${ }^{(36,39)}$.

Disseminated intravascular coagulation is a dynamic process and the tests conducted reflect only the conditions at any given moment in time. In clinical circumstances associated with this condition repeating these tests aids in establishing the diagnosis. Tests used in assessing the hemostatic state provide information about the clinical course. Prothrombin time (PT), activated partial thromboplastin (aPTT) and thrombocyte count reflect the consumption and activation of thrombocytes $(40)$. The laboratory finding showing fibrin production is made indirectly by measuring the fibrin degradation product, D-Dimer ${ }^{(41)}$. In a multicenter meta-analysis the most frequent encountered abnormal laboratory findings in DIC were listed as thrombocytopenia, increased fibrin degradation products, prolonged PT, aPTT and low fibrinogen levels ${ }^{(42-46)}$. In a study reported by Spero et al, thrombocytopenia was noted in $98 \%$ of patients, while severe thrombocytopenia $\left(<50 \times 10^{9} / 1\right)$ was noted in $50 \%$ of patients $(45)$. In another study, it was postulated that low platelet counts could be an indicator of increased thrombin production(47). Thrombocyte aggregation related to thrombin is the the main reason of thrombocyte consumption(48).

Fibrin degradation products (FDPs) and D-Dimer are tests used in the diagnosis of DIC, however, a diagnosis of DIC can not be established based only on an elevated D-Dimer. Along with the rise in D-Dimer levels, a decrease in the thrombocyte counts and changes in the coagulation time have been accepeted as important laboratory findings of DIC(49).

A prolonged PT and aPTT is seen in $50-69 \%$ of cases ${ }^{(50)}$. This condition is related to the consumption of the coagulation factors. Since, a normal or even shortened PT and aPTT level is seen in half of the Disseminated Intravascular Coagulation cases, repeating these test in the follow-up of these patients is highly important ${ }^{(51)}$.

Although, fibrinogen is a frequently used test in the diagnosis of DIC, it is considered as a less specific test ${ }^{52}$. Fibrinogen is an acute phase reactant and plasma levels, therefore, may run for a long period of time within normal limits independent of the consumption of coagulation factors. In a study, the specificity of low fibrinogen levels in the diagnosis of DIC was reported as $28 \%$ and hypofibrinogenemia was noted only in severe DIC cases ${ }^{(53)}$. In another study, $57 \%$ of DIC cases were noted to have normal fibrinogen levels ${ }^{(45)}$. Therefore, measurement of serial fibrinogen levels in these patients is essential as it provides us diagnostic clues.

In contrast to classical DIC cases, during pregnancy, the reliability of tests used in the diagnosis of DIC is limited due to a rise in the serum levels of coagulation 
factors ${ }^{(54)}$. In pregnancy, PT and aPTT levels shorten based on the increase in coagulation factors. During pregnancy, even if the consumption of coagulation factors associated with DIC leads to prolongation of PT and aPTT levels, they may still be within normal limits. For this reason, serial measurements are vital in the diagnosis of evolving DIC(55). Similarly, physiological thrombocytopenia associated with pregnancy should be considered while diagnosing DIC. In serial analyses, the decline in platelet counts provides information about the increase in thrombin formation and the associated development of DIC(56). Levels of Fibrinogen, an acute phase reactant, rise in pregancy. In a study analysing 535 patients with an overt diagnosis of non-pregnancy associated DIC, only 46 patients $(8.6 \%)$ were noted to have a low fibrinogen level (less than $1 \mathrm{gm} / \mathrm{L})^{(52)}$. Considering the double fold increase in baseline fibrinogen levels during pregnancy, it is not surprising to encounter fibrinogen levels which are within normal limits in patients with a suspicion of DIC ${ }^{(57)}$. Furthermore, Fibrinogen levels are used as an indicator of the severity of portpartum bleeding ${ }^{(58)}$. Since, D-Dimer levels are already elevated in pregnancy, only a significant rise in serial measurements may aid in the diagnosis of DIC ${ }^{(59)}$. As a result of the above mentioned reason, the yield of diagnostic tools used in DIC shows a difference in DIC associated with obstetrical causes comapred with classical DIC. In methods, such as the thromboelastography (TEG) and rotational TEG (ROTEG), the path from the initiation of clot formation to fibrinolysis, including thrombocyte functions is considered as a whole ${ }^{(39)}$. In these methods, the coagulation is activated by spinning the blood in a pool. For example, a sensor placed inside, enables accurate measurements of the speed and structural strength of clot formation. Thus, activation of the coagulation systems, thrombocyte functions and analysis of fibrinolysis can be achieved. In contrast to conventional coagulation tests, in the TEG system, other than tracking the elapsed time for the clot formation, the quality of clot formed is assessed as well. Therefore, the hemostatic system is analyzed both quantitatively and qualitatively. Thromboelastography is a frequently prefered diagnostic method test as it can be performed at bedside, i.e., point of care testing (POC testing). Clinically, it's especially used in cardiac surgery and liver transplantations $(60)$. TEG, aids in rapid diagnosis of DIC suspected cased, providing an opportunitty to address the dysfunction in the coagulation systems $(61)$.

\section{Scoring used in Disseminated Intravascular Coagulation}

There is no single test to diagnose DIC. The International Society of Thrombosis ve Hemostasis (ISTH) developed a scoring system for the diagnosis of DIC thus easing the diagnosis and management ${ }^{(62)}$. The flow chart of this scoring system (Figure 4) is only appropriate for patients with an underlying disorder that can be associated with DIC. The scoring is done based on the thrombocyte count, Fibrin split products, D-Dimer, prolonged aPTT and fibrinogen levels. A score of 5 and higher is considered as overt DIC. The DIC scoring by ISTH can be used in cases both with and wihout underlying infectious ${ }^{(63)}$. Bakhtiari et al

Figure 4: International Society of Thrombosis ve Hemostasis (ISTH) DIC Scoring System.

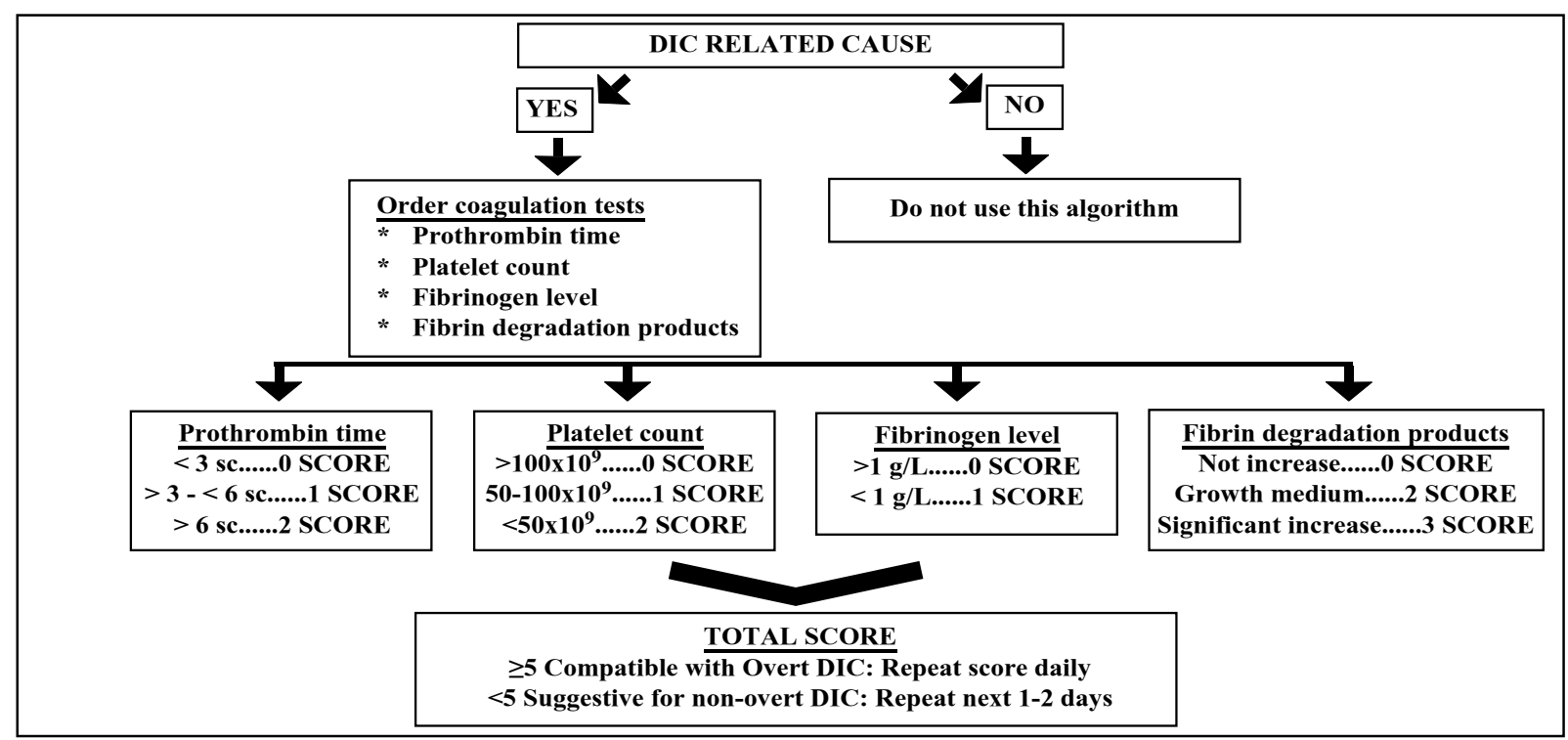


reported the sensitivity of the ISTH DIC scoring system as $97 \%$ and specifity as $91 \%$. The strong relationship betwen the scoring system and mortality has been demonstrated in a few studies. For every 1 point increase in the score, ghe mortality was noted to rise between $1 / 25$ to $1 / 29^{(64)}$.

\section{TREATMENT}

The main goal of the treatment in DIC is to correct the underlying obstetrical cause. Once the precipitating cuase is addressed DIC usually resolves. Besides, supportive treatment should be implemented to correct the coagulation disorder(36). The following section comprises this part of the clincial management.

\section{Replacement of Blood and Blood products}

The decision for replacement of blood products is given after consideration of laboratory results and the clinical condition all toghether. In general, platelet suspensions are administered to patients with platelet counts less than $50 \times 10^{9}$ and actively bleeding. In patients without bleeding, platelet transfusion is limited to patient's with a platelet count with less than $30 \times 10^{9} \mathrm{dir}^{(65)}$. There is no indication to transfuse coagulation factors and plasma if there is no active bleeding. However, if the active bleeding occurs is in the setting of prolonged PT and aPTT, then Fresh Frozen Plasma (FFP) should be administered at a dose of $10-20 \mathrm{ml} / \mathrm{kg}^{(65)}$.Higher doses may be administered based on response noted during serial follow-up testing. If FFP's are not feasible due to concerns of fluids overload, non-activated prothrombin complex concentrate (PCC) may be administered at $25-30 \mathrm{U} / \mathrm{kg}$ dose ${ }^{(66)}$. Since this concentrate, contains only Vitamin K dependent factors it will replace the deficit partially. As it may worsen the severity of the dissesminated intravascular coagulation activated PCC should not be used, instead only nonactivated PCC should be used(67).

In congenital isolated fibrinogen deficiencies with levels less then $1 \mathrm{gm} / \mathrm{L}$, cryoprecipitate or fibrinogen factor concentrates should be used. Since the fibrinogen consumption may be faster, fibrinogen concentrates should be administered for values above $1 \mathrm{gm} / \mathrm{L}$ in DIC. 4 gm of fibrinogen concentrates, increase serum fibrinogen levels to $1 \mathrm{gm} / \mathrm{L}^{(68)}$. In a study done on 30 patients with acquired hypofibrinogenemia, i.e. $(<1.5 \mathrm{~g} / \mathrm{lt})$, it was shown that the bleeding stopped without any further surgical or radiological intervention in $46 \%$ of the cases. In the same study, no adverse effects, including thromboembolic events related to the use fibrinogen concentrate were noted ${ }^{(69)}$.

\section{Management of the Massive Bleeding}

Obstetrical bleedings are the most common reason of maternal mortality. In a healthy female, there may be no alterations in vital signs until $10-15 \%$ of the blood volume has been lost. Tachycardia is the first finding of bleeding. $30 \%$ of the blood volume may have been lost by the time that severe hypotension is noted ${ }^{(70)}$. Management of postpartum bleeding warrants medical, mechanical and surgical interventions requiring significant amount of blood and blood products ${ }^{(71)}$.

In obstetrical bleedings, the replacement of blood and blood products should be similar to the approach to trauma patients ${ }^{(72)}$. Management of massive obstetrical bleeding is summarized in Table I. The purpose of management of bleeding is to maintain the patient normotensive, normothermic and ensure adequate replacement of clotting factors. First of all, two large bore peripheral IV lines should be placed. Initiation of crystalloid or colloid fluids remains a controversy because colloid solutions may affect coagulation ${ }^{(73)}$. Rapid transfusion of volume expanders may lead to dilution of coagulation factors. Therefore, blood replacement should be implemented as soon as possible. $\mathrm{O} \mathrm{Rh}$ negative blood transfusion must be started emergently and typed \& screened, cross matched blood should be prepared within maximum 45 minutes $^{(65)}$.

Table I: Management of Massive obstetrical bleeding (Reference \#65 is used in to build this figure).

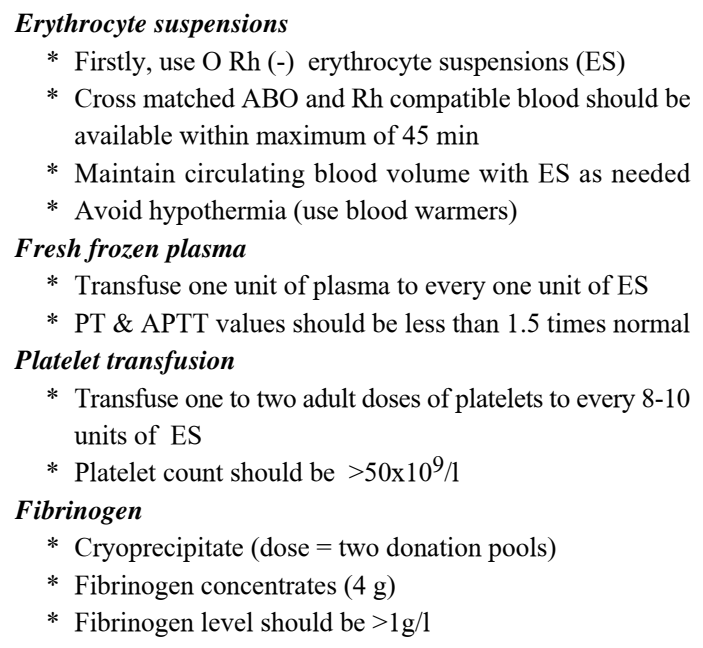


A study done by Hishberg et al showed that dilutional coagulopathy could be inevitable with more than 5units of blood tranfusion( ${ }^{74)}$. In another study done, use of 1:1 packed red blood cells and FFPs was demonstrated to decrease the mortality $(75,76)$. In another study, it was reported that prophylactic administration of thrombocytes decreased the need for other blood products in massive bleedings. Therefore, the need for 1-2 adult dosing thrombocyte replacement for every 8-10 units of blood is emphasized(77).

There is literature demonstrating that administration of cyroprecipitates and fibrinogens for fibrinogen levels less than $1.5 \mathrm{gm} / \mathrm{L}$ decreaeses bleeding $(78,79)$. In a retropective study, the use of fibrinogen concentrates decreased the need for erythrocyte and thrombocyte suspesions, FFPs as well as led to a significant decrease in blood loss and improved coagulation factors. The reported study includees mainly obstetrical cases and suported the use of fibrinogen factor concentrates in placental abruption and placenta previa( ${ }^{(78)}$. Serial measurement of whole blood count and coagulation parameters are essential in regards to whether to carrying on or hold further replacement of blood products. Caution should be given to prevent development of acidosis and hypothermia associated with transfusions. In massive transfusions, it has been shown that acidosis hinders the union of the coagulation complex and that hypothermia decreases thrombocyte activation ${ }^{(80)}$. In massive obstetrical bleeding followign steps should be ensured in order

1. The bleeding should be controlled with surgical and radiological methods.

2. The circulating blood volume should be replaced with fluids and blood products and

3. Factors like, hypothermia and acidosis triggering abnormal coagulation should be controlled. The management of blood products should be done as listed in Table I.

\section{The role of activated Factor VII}

The experience with the use recombinant Factor VIIa (rFVIIa) in massive obstetrical bleedings is increasing. Gabriel et al discovered that rFVIIa levels above physiological limits are directly activating Factor $\mathrm{X}$ located on the surface of activated platelets ${ }^{(81)}$. A study reviewing the Northern Europian Obstetric records, demonstarted that the bleeding was effectively controlled in $83 \%$ of patints who were treated with $\mathrm{FVIIa}^{(82)}$. In another prospective study, the use of rFVIIa in patients with postpartum bleeding was shown to prevent from postpartum hysterectomy by $91 \%(83)$.

However, yet there are questions regarding the use of rFVIIa which need to be answered. First of all, the dose to be used in massive obstetric bleedings has not been standardized, yet. Various groups used doses ranging from $15 \mathrm{mcg} / \mathrm{kg}$ to $120 \mathrm{mcg} / \mathrm{kg}^{(65)}$. Secondarily, in cases with platelet counts above $100 \times 10^{9}$ and less severe coagulopathies the response to rFVIIa is higher. This finding supports the replacement with blood products early on in the course to bring the response to rFVIIa to a more adequate level. Acidosis and low fibrinogen levels decrease the optimum response to $\mathrm{rFVIIa}^{(84)}$. As a pre-hemostatic agent, rFVIIa may theoretically lead to thromboembolic complications. Especially, in hypercoagulable states like pregancy this could become a problem of importance. In a recent review, only one out of 48 patients who who were treated with rFVIIa developed a thromboembolic complication ${ }^{(85)}$. Another reason is that the costs of rFVIIa treatment are high. However, if the surgical procedures and prolonged hospital stay including admission to the ICU are considered as well it may balance out.

Although, rFVIIa seems to be an effective treatment method in massive obstetrical bleedings there is need for further research in regards to optimum dosing, frequency and proper timing of use.

\section{Pharmacological Treatment}

The use of pharmacological agents inhibiting the coagulation and fibrinolytic systems in Disseminated Intravascular Coagulation is still controversial. Heparin will theoretically inhibit intravascular coagulation and subsequent fibrinolysis through inhibition of the thrombin activity.

Heparin is especially recommended in DIC cases associated with thrombosis without stigmata of bleeding. In patients considered for Heparin treatment, fractionated heparin should be the treatment of choice given its short half life and reversible actions and should be administered as continuous intravenous infusion at $10 \mu / \mathrm{kg} / \mathrm{hr}$. In these patients, the clinical response should be taken into account rather then the use aPTT in the monitorization of the anticoagulant effect ${ }^{(36)}$. The use of anti-fibrinolytic agents such as Tranexamic asit and $B$-aminocaproic acid is in general contraindicated in DIC. However, these medications may be effective in life threatening bleedings ${ }^{(86)}$. 


\section{REFERENCES}

1. Williams J, Mozurkewich E, Chilimigras J, Van De Ven C. Critical care in obstetrics: pregnancy-specific conditions. Best Pract Res Clin Obstet Gynaecol 2008;22(5):825-46.

2. DeLee JB. A case of fatal hemorrhagic diathesis, with premature detachment of the placenta. Am J Obstet Dis Women Child 1901;44:785-92.

3. Bick RL. Disseminated intravascular coagulation: a review of etiology, pathophysiology, diagnosis, and management: guidelines for care. Clin Appl Thromb Hemost 2002;8(1): $1-31$.

4. Bick RL. Disseminated intravascular coagulation current concepts of etiology, pathophysiology, diagnosis, and treatment. Hematol Oncol Clin North Am 2003;17(1):149-76.

5. Bick RL. Syndromes of disseminated intravascular coagulation in obstetrics, pregnancy, and gynecology. Objective criteria for diagnosis and management. Hematol Oncol Clin North Am 2000;14(5):999-1044.

6. Liang BL, Hong DH. Diagnosis and management of obstetric acute disseminated intravascular coagulation. Zhonghua $\mathrm{Fu}$ Chan Ke Za Zhi 1992;27(3):147-9, 188.

7. Kor-anantakul O, Lekhakula A. Overt disseminated intravascular coagulation in obstetric patients. J Med Assoc Thai 2007;90(5):857-64.

8. Rattray DD, O'Connell CM, Baskett TF. Acute disseminated intravascular coagulation in obstetrics: A tertiary centre population review (1980 to 2009). J Obstet Gynaecol Can 2012;34(4):341-7.

9. Kobayashi T, Terao T, Maki M, Ikenoue T. Diagnosis and management of acute obstetrical DIC. Semin Thromb Hemost 2001;27(2):161-7.

10. Oyelese Y, Ananth CV. Placental abruption. Obstet Gynecol 2006;108(4):1005-16

11. Kramer MS, Usher RH, Pollack R et al. Etiologic determinants of abruptio placentae. Obstet Gynecol 1997;89(2):221-6.

12. Han CS, Schatz F, Lockwood CJ. Abruption-associated prematurity. Clin Perinatol 2011;38(3):407-21.

13. Ananth CV, Getahun D, Peltier MR et al. Placental abruption in term and preterm gestations: evidence for heterogeneity in clinical pathways. Obstet Gynecol 2006;107(4):785-92.

14. Hess JR. Blood and coagulation support in trauma care Hematol Am Soc Hematol Educ Program 2007;187-91.

15. Redman CW, Sacks GP, Sargent IL. Preeclampsia: an excessive maternal inflammatory response to pregnancy. Am J Obstet Gynecol 1999;180(2 Pt 1):499-506.

16. Savvidou MD, Hingorani AD, Tsikas D et al. Endothelial dysfunction and raised plasma concentrations of asymmetric dimethylarginine in pregnant women who subsequently develop pre-eclampsia. Lancet 2003;361(9368):1511- 7.

17. Redman CW. Platelets and the beginnings of preeclampsia. N Engl J Med 1990;323(7):478-80.

18. Martin JN, Rose CH, Briery CM. Understanding and managing HELLP syndrome: the integral role of aggressive glucocorticoids for mother and child. Am J Obstet Gynecol 2006;195(4):914-34.

19. Fang CJ, Richards A, Liszewski MK, et al. Advances in understanding of pathogenesis of HUS and HELLP. Br J Haematol 2008;143(3):336-48.

20. Boisramé-Helms J, Kremer H, Schini-Kerth V, Meziani F. Endothelial dysfunction in sepsis. Curr Vasc Pharmacol 2013; 11(2):150-60.

21. Högberg U, Joelsson I. Amniotic fluid embolism in Sweden, 1951-1980. Gynecol Obstet Invest 1985;20(3):130-7.

22. Clark SL, Hankins GD, Dudley DA, Dildy GA, Porter TF. Amniotic fluid embolism: analysis of the national registry. Am J Obstet Gynecol 1995;172(4 Pt 1):1158- 67.

23. Yang W, Zhou N, Zhou Y. The clinical analysis of 38 cases with amniotic fluid embolism [Chinese]. Zhonghua Fu Chan Ke Za Zhi 2000;35(2):75-8.

24. Abenhaim HA, Azoulay L, Kramer MS, Leduc L. Incidence and risk factors of amniotic fluid embolisms: a populationbased study on 3 million births in the United States. Am J Obstet Gynecol 2008;199(1):49.e1-8.

25. Sullivan EA, King JF. Maternal deaths in Australia 20002002. Maternal deaths series no. 2. Cat. no. PER 32. Sydney: AIHW National Perinatal Statistics Unit; 2006.

26. Lewis G. The confidential enquiry into maternal and child health (CEMACH). Saving mothers' lives: reviewing maternal deaths to make motherhood safer-2002-2005. The seventh report on confidential enquiries into maternal deaths in the United Kingdom. London: CEMACH; 2007.

27. Dey M, Reema K. Acute fatty liver of pregnancy. N Am J Med Sci 2012;4(11):611-2.

28. Bacq Y. Acute fatty liver of pregnancy. Semin Perinatol 1998; 22(2):134-40.

29. Castro MA, Goodwin MT, Shaw KJ, et al. Disseminated intravascular coagulation and antithrombin III depression in acute fatty liver of pregnancy. Am J Obstet Gynecol 1996; 174(1 Pt 1):211-6.

30. Hoffman M, Monroe DM. Coagulation 2006: a modern view of hemostasis. Hematol Oncol Clin North Am 2007;21(1):1-11.

31. Tetik S, Kaya K, Yardimci T. Effect of oxidized fibrinogen on haemostatic system: in vitro study. Clin Appl Thromb Hemost 2011;17(3):259-63.

32. Bremme KA. Haemostatic changes in pregnancy. Best Pract Res Clin Haematol 2003;16(2):153-68. 
33. DahlmanT, Hellgren M, Blomback M. Changes in blood coagulation and fibrinolysis in the normal puerperium. Gynecol Obstet Invest 1985;20(1):37-44.

34. O'Riordan MN, Higgins JR. Haemostasis in normal and abnormal pregnancy. Best Pract Res Clin Obstet Gynaecol 2003;17(3):385-96.

35. Tetik S, Ak K, Sahin Y, Isbir S, Gulsoy O, Arsan S, Yardimci T. Postoperative statin therapy attenuates the intensity of systemic inflammation and increases fibrinolysis after coronary artery bypass grafting. Clin Appl Thromb Hemost 2011;17(5): 526-31.

36. Levi M, Toh CH, Thachil J, Watson HG. Guidelines for the diagnosis and management of disseminated intravascular coagulation: British Committee for Standards in Haematology. Br J Haematol 2009;145(1):24-33.

37. Gando S, Iba T, Eguchi Y et al. A multicenter, prospective validation of disseminated intravascular coagulation diagnostic criteria for critically ill patients: comparing current criteria. Crit Care Med 2006;34(3):625-31.

38. Çakmakçı M. Abdominal kompartman sendromu. T Klinikleri Cerrahi Dergisi 1998;3:51-4.

39. Ak K, Isbir C, Tetik S, Atalan N, Tekeli A, Aljodi M et al. Thromboelastography based transfusion algorithm reduces blood product use after elective $\mathrm{CABG}$ : A prospective randomized study. J Card Surg 2009;24(4):404-10.

40. Tetik Ş, Ak K, Yardımcı KT. The factors effecting platelet function tests. Cumhuriyet Tip Der 2012;4:123-7.

41. Bick RL, Baker WF. Diagnostic efficacy of the D-dimer assay in disseminated intravascular coagulation (DIC). Thrombosis Research 1992;65(6):785-90.

42. Al-Mondhiry. Disseminated intravascular coagulation: experience in a major cancer center. Thrombosis et Diathesis Haemorrhagica 1975;34(1):181-93.

43. Siegal T, Seligsohn U, Aghai E Modan M. Clinical and laboratory aspects of disseminated intravascular coagulation (DIC): a study of 118 cases. J Thromb Haemost 1978;39(1): 122-34.

44. Mant MJ, King EG. Severe, acute disseminated intravascular coagulation. A reappraisal of its pathophysiology, clinical significance and therapy based on 47 patients. Am J Medicine 1979;67:557-63.

45. Spero JA, Lewis JH, Hasiba U. Disseminated intravascular coagulation. Findings in 346 patients. J Thromb Haemost 1980;43(1):28-33.

46. Wilde JT, Kitchen S, Kinsey S, Greaves M, Preston FE. Plasma D-dimer levels and their relationship to serum fibrinogen/fibrin degradation products in hypercoagulable states. Br J Haematol 1989;71(1):65-70.
47. Neame PB, Kelton JG, Walker IR, Stewart IO, Nossel HL, Hirsh, J. Thrombocytopenia in septicemia: the role of disseminated intravascular coagulation. Blood 1980;56(1): 88-92.

48. Akca S, Haji-Michael P, de MA, Suter P, Levi M, Vincent JL. Time course of platelet counts in critically ill patients. Crit Care Med 2002;30(4):753-6.

49. Carr, J.M., McKinney, M. \& McDonagh, J. Diagnosis of disseminated intravascular coagulation. Role of D-dimer. Am J Clin Pathol 1989;91(3):280-7.

50. Bick, R.L. Disseminated intravascular coagulation: objective clinical and laboratory diagnosis, treatment, and assessment of therapeutic response. Semin Thromb Hemost 1996;22(1): 69-88.

51. Asakura H, Ontachi Y, Mizutani T, Kato M., Ito T, Saito M. Decreased plasma activity of antithrombin or protein $\mathrm{C}$ is not due to consumption coagulopathy in septic patients with disseminated intravascular coagulation. Eur J Haematol 2001; 67(3):170-5.

52. Levi M, Ten $\mathrm{CH}$. Disseminated intravascular coagulation. $\mathrm{N}$ Engl J Med 1999;341(8):586-92.

53. Levi, M., de, J.E., van der, P.T. \& Ten, C.H. Disseminated intravascular coagulation. J Thromb Haemost 1999;82(2): 695-705.

54. O'Riordan MN, Higgins JR. Haemostasis in normal and abnormal pregnancy. Best Pract Res Clin Obstet Gynaecol 2003;17(3):385-96.

55. Wallenburg HC, van Kessel PH. Platelet lifespan in normal pregnancy as determined by a non-radioisotopic technique. BJOG 1978;85(1):33-6.

56. Neame PB, Kelton JG, Walker IR, et al. Thrombocytopenia in septicemia: the role of disseminated intravascular coagulation. Blood 1980;56(1):88-92.

57. Manten GT, Franx A, Sikkema JM, et al. Fibrinogen and high molecular weight fibrinogen during and after normal pregnancy. Thromb Res 2004;114(1):19-23.

58. Charbit B, Mandelbrot L, Samain E. The decrease of fibrinogen is an early predictor of the severity of postpartum hemorrhage. J Thromb Haemost 2007;5(2):266-73.

59. Nieuwenhuizen W. A reference material for harmonisation of D-dimer assays. Thromb Haemost 1997;77(5):1031-3.

60. Tetik Ş, Ak K. Platelet function tests on cardiovascular dieases: from pathophysiology to clinical approach. Cumhuriyet Med J 2010;32:264-74.

61. Sharma P, Saxena R. A novel thromboelastographic score to identify overt disseminated intravascular coagulation resulting in a hypocoagulable state. Am J Clin Pathol 2010;134(1):97-102.

62. Taylor FB, Toh CH, Hoots WK, Wada H, Levi M. Towards 
definition, clinical and laboratory criteria, and a scoring system for disseminated intravascular coagulation. J Thromb Hemost 2001;86(5):1327-30.

63. Gando S, Wada H, Asakura H, Iba T, Eguchi Y, Okamoto K. Evaluation of new Japanese diagnostic criteria for disseminated intravascular coagulation in critically ill patients. Clin Appl Thromb Hemost 2005;11(1):71-6.

64. Bakhtiari K, Meijers JC, Levi M. Prospective validation of the international society of thrombosis and haemostasis scoring system for disseminated intravascular coagulation. Crit Care Med 2004;32(12):2416-21.

65. Thachil J, Toh CH. Disseminated intravascular coagulation in obstetric disorders and its acute haematological management. Blood Rev 2009;23(4):167-76.

66. Josic D, Hoffer L, Buchacher A. Manufacturing of a prothrombin complex concentrate aiming at low thrombogenicity. Thromb Res 2000;100(5):433-41.

67. Preston FE, Laidlaw ST, Sampson B. Rapid reversal of oral anticoagulation with warfarin by a prothrombin complex concentrate (Beriplex): efficacy and safety in 42 patients. $\mathrm{Br}$ J Haematol 2002;116(3):619-24.

68. Kreuz W, Meili E, Peter-Salonen K. Efficacy and tolerability of a pasteurised human fibrinogen concentrate in patients with congenital fibrinogen deficiency. Transfus Apher Sci 2005; 32(3):247-53.

69. Weinkove R, Rangarajan S. Fibrinogen concentrate for acquired hypofibrinogenaemic states. Transfus Med 2008;18(3):151-7.

70. Wise A, Clark V. Strategies to manage major obstetric haemorrhage. Curr Opin Anaesthesiol 2008;21(3):281-7.

71. Kayabasoglu F, Guzin K, Aydogdu S, Sezginsoy S, Turkgeldi L, Gunduz G. Emergency peripartum hysterectomy in a tertiary Istanbul hospital. Arch Gynecol Obstet 2008;278(3):251-6.

72. Stainsby D, MacLennan S, Thomas D, Isaac J, Hamilton PJ. BCSH guidelines on the management of massive blood loss. Br J Haematol 2006;135(5):634-41.

73. Van der Linden P, Ickx BE. The effects of colloid solutions on hemostasis. Can J Anaesth 2006;53(6 Suppl):S30-9.

74. Hirshberg A, Dugas M, Banez E, Scott B, Wall M, Mattox K. Minimizing dilutional coagulopathy in exanguinating hemorrhage: a computer simulation. J Trauma 2003;54(3): 454-61.

75. Malone DL, Hess JR, Fingerhut A. Massive transfusion practices around the globe and a suggestion for a common massive transfusion protocol. J Trauma 2006;60(6 Suppl):S916.

76. Borgman MA, Spinella PC, Perkins JG, et al. The ratio of blood products transfused affects mortality in patients receiving massive transfusions at a combat support hospital. J Trauma 2007;63(4):805-13.

77. Johansson PI, Stensballe J, Rosenberg I, et al. Proactive administration of platelets and plasma for patients with a ruptured abdominal aortic aneurysm: evaluating a change in transfusion practice. Transfusion 2007;47(4):593-8.

78. Fenger-Eriksen C, Lindberg-Larsen M, Christensen AQ, et al. Fibrinogen concentrate substitution therapy in patients with massive haemorrhage and low plasma fibrinogen concentrations. Br J Anaesth 2008;101(6):769-73.

79. Wikkelsoe AJ, Afshari A, Stensballe J, Langhoff-Roos J, Albrechtsen $\mathrm{C}$ et al. The FIB-PPH trial: fibrinogen concentrate as initial treatment for postpartum haemorrhage: study protocol for a randomised controlled trial. Trials 2012;13:110.

80. Meng ZH, Wolberg AS, Monroe 3rd DM. The effect of temperature and $\mathrm{pH}$ on the activity of factor VIIa: implications for the efficacy of high-dose factor VIIa in hypothermic and acidotic patients. J Trauma 2003;55(5):886-91.

81. Gabriel A, Li X, Monroe DM. Recombinant human factor VIIa, (rFVIIa) can activate FX on activated platelets. J Thromb Haemost 2004;2(10):1816-22.

82. Sobieszczyk S, Breborowicz GH, Platicanov V, et al. Recombinant factor VIIa in the management of postpartum bleeds: an audit of clinical use. Acta Obstet Gynecol Scand 2006;85(10):1239-47.

83. Franchini M, Lippi G, Franchi M. The use of recombinant activated factor VII in obstetric and gynaecological haemorrhage. BJOG 2007;114(1):8-15.

84. Haynes J, Laffan M, Plaat F. Use of recombinant activated factor VII in massive obstetric haemorrhage. Int J Obstet Anesth 2007;16(1):40-9.

85. Butwick AJ. Postpartum hemorrhage and low fibrinogen levels: the past, present and future. Int J Obstet Anesth 2013; 22(2):87-91.

86. Novikova N, Hofmeyr GJ. Tranexamic acid for preventing postpartum haemorrhage. Cochrane Database Syst Rev 2010; (7):CD007872. 